TITLE:

\title{
NANOG maintains self-renewal of primate ES cells in the absence of a feeder layer(Abstract_要旨)
}

\author{
AUTHOR(S): \\ Yasuda, Shinya
}

\section{CITATION:}

Yasuda, Shinya. NANOG maintains self-renewal of primate ES cells in the absence of a feeder layer. 京都大学, 2007, 博士(医学)

ISSUE DATE:

2007-03-23

URL:

http://hdl.handle.net/2433/135674

RIGHT: 


\begin{abstract}
氏
学位 (専攻分野)

学位記 番号

学位授与の日付

学位授与の要件

研究科・尃攻

学位論文題目
\end{abstract}

論文調查委員
安望望晋也

博士（医学）

医 博 第 3054 号

平成 19 年 3 月 23 日

学位規則第 4 条第 1 項該当

医学研究科分子医学系専攻

NANOG maintains self-renewal of primate ES cells in the absence of a feeder layer

（NANOG は霊長類 ES 細胞の未分化性を維持する）

(主 查)

教授山中伸弥教授中畑龍俊教授篠原隆司

\section{論文 内容の 要旨}

ヒト肧性幹細胞（ES 細胞）は発生過程の三肧葉へ分化する能力を持ち，その分化能を保持した状態で增殖可能である。 $\mathrm{ES}$ 細胞は三肧葉を起源とする全ての細胞に分化可能と考えられるため, 体組織の様々な細胞に分化誘導し, 細胞移植医療 に応用することが期待されている。多分化能（未分化性）を維持した ES 細胞は通常フィーダー細胞上で培養され，フィー ダー細胞非存在下では未分化性を維持して安定に培養することが困難である。また，培養液には多くの動物由来成分を必要 とする。しかし ES 細胞が異種動物由来の成分に接触することは感染性因子が混入する危険性もあり臨床応用上からは好ま しくない。そこでフィーダー細胞や動物由来因子非存在下で霊長類 ES 細胞を安定に維持する条件を探索するため, ES 細 胞の未分化性維持機構の研究を進めている。

本研究ではホメオドメインを持つ転写因子 NANOG に着目し，ヒト及びサル ES 細胞で実験を行った。Nanog はマウス ES 細胞の未分化性維持に必須であり，発現維持することでフィーダー細胞非依存的に未分化性を維持することが報告され ている。そこで, 本研究では霊長類 ES 細胞での NANOG の機能をヒト及びカニクイザルの ES 細胞を使用して解析した。

まずNANOG がヒト，サル ES 細胞でも未分化特異的に発現していることをWestern blot 法で調べた。フィーダー細胞 を取り除くとサル ES 細胞は分化し，Oct-4，ALP などの未分化特異的マーカーの発現は消失するとともに，NANOGの 発現も同時に消失した。NANOG がヒト及びサル ES 細胞でも未分化性維持に関与している可能性を検討するために NANOG 発現プラスミドをES 細胞に導入し，NANOG を恒常的に高発現する細胞株を作製した。ヒト ES 細胞では遺伝 子導入効率が低いために，遺伝子導入試薬のスクリーニング及び最適化を行った。作製されたNANOG 高発現株はフィー ダー細胞非存在下でも形態的に未分化であり, また未分化特異的マーカーの発現も維持されていた。次にNANOG 高発現 株で肧様体作製により分化を誘導したところ，野生株では三胚葉㧍よび肧体外組織の分化が認められたのに対し， NANOG 高発現株では内胚葉, 栄養外胚葉の分化マーカーの発現が抑制されていた。また NANOGの siRNAを導入して knockdownすると内胚葉マーカー㧍よび栄養外胚葉マーカーの発現が強く誘導された。これらの結果から NANOG 遺伝 子は霊長類 $\mathrm{ES}$ 細胞に扔いてもその未分化性維持に重要な機能を果たしていると考えられる。

本研究ではサル, 及びヒト ES 細胞の未分化性維持機構の重要なファクターを明らかにし, 効率の良い遺伝子導入法が確 立できた。これらはヒト ES 細胞を治療に用いる際の重要な情報であるとともに基礎生物学的研究にも貢献できることが期 待される。

\section{論文 審査の結果の要旨}

本論文は，マウスで同定された未分化特異的遺伝子 NANOG の特性や機能を霊長類 ES 細胞で解析したものである。 霊長類未分化 ES 細胞に扔いては未分化特異的マーカーである OCT-4, ALP と共にNANOG が発現している。しかし， 未分化性を失うと OCT -4, ALP の消失にともない NANOG の発現も消失することを確認した。次にNANOG の強制発 
現による機能解析を行い，霊長類 ES 細胞は外来性 NANOG を発現維持することにより，フィーダー細胞が無い状態でも 内肧葉，中胚葉，栄養外胚葉への分化を抑制して，未分化性を維持することを示した。さらに野生株の NANOGをノック ダウンすると内胚葉，栄養外胚葉へ分化することを示した。申請者はこれらの結果から，NANOG が霊長類 ES 細胞の未 分化性維持に必須な因子であることを明らかにしている。

以上の研究はヒト, サルの ES 細胞で未分化性維持の鍵となる NANOG の機能の解明に貢献し, 霊長類 ES 細胞の未分 化性維持機構の理解に寄与するところが多い。

したがって, 本論文は博士 (医学) の学位論文として価値あるものと認める。

なお，本学位授与申請者は平成19年 1 月 12 日実施の論文内容とそれに関連した諮問を受け，合格と認められたものである。 